\title{
Tourism Attractions and Visitors Perceptions on "Negeri di Atas Awan", A New Tourist Destination in Citorek Kidul Lebak Banten
}

\author{
Fifi Nofiyanti*, Ira Mayasari, Boby Dimas Parwoto \\ Sekolah Tinggi Pariwisata Trisakti \\ *fifi.nofiyanti17@stptrisakti.ac.id
}

\begin{abstract}
This study aims to determine the tourist attraction and perceptions of visitors on the new tourists' destination called Negeri di atas Awan (the country above the clouds) located in Citorek Kidul Village, Lebak Banten, Indonesia. This tourist destination was viral in September 2019 was briefly used by several citizens, because Lebak Banten has never been heard of having a tourist destination. The area is 900 meters above sea level. This research method is qualitative with a case study approach. By using this type of case study research, this study intends to provide a description of the Tourism Attraction and Perceptions in Citorek Kidul Lebak Village, Banten, which is being viral on social media. The study was conducted in the Citorek Kidul Lebak Village, Banten, which is known for its country tourism on clouds. The results of this study are the tourist attraction of "Negeri di Atas Awan" which is a view of the clouds formed by the cold weather in Citorek Village. This view can only be enjoyed at 05.00 - 08.00 WIB. Public facilities at the tourist site "Negeri di Atas Awan" are complete, the manager is Pokdarwis and residents who have a business together to build this location with public facilities, such as: toilets, parking, small mosque, ticket purchase counters, homestays, and restaurants. The results of the visitor's perception of the study expressed satisfaction, because news that was released through social media turned out to be true.
\end{abstract}

Keywords: tourist attraction, visitor perception, Negeri di Atas Awan 


\section{A. Introduction}

This millennial era is a destination for people to do routine activities. Travel options sometimes have become a plan for family, relatives, and relatives. Tourism can strengthen brotherhood and reduce stress levels and tired of activity. Attractions can be said of everything in the tourist destination that becomes an attraction for tourists who come to the location. Some of the instagramable tourist attractions are targeted by teenagers, parents and children. Initially there were many selfie or wefie tours in Bandung, but now they are spread in various places in Indonesia.

Some time this is being hits or famous tourist about Negeri di Atas Awan which is located on Mount Luhur, Citorek Village, Banten. This viral tour was uploaded on Facebook and Instagram social media which can make tourists curious and want to visit it. According to Acep Nazmudin (2019) in Kompas.Com conveyed, "since the viral on social media Gunung Luhur in Citorek Kidul Village, Cibeber District, Lebak Regency, Banten was crowded with visitors reaching a record 30,000 tourists". Crowds of tourists who are persuaded to see directly the country above the clouds of Banten Citorek Village became the center of attention of researchers. Therefore, we as researchers want to find out more about Tourism Attractions and Visitors Perceptions on "Negeri di Atas Awan", Tourist Destination in Citorek Kidul Lebak Banten In this study, we want to find out the causes of viral and the high number of visitors to the country's tourist sites above the clouds.

\section{B. Literature Review \\ Travel Attractions}

According to Cooper et al in Sunaryo (2013: 159) explains that the framework of the development of tourism destinations consists of the main components as follows:

a) Objects of attraction which include the uniqueness and appeal of nature, culture, and artificial.

b) Accessibility which includes the ease of transportation facilities and systems.

c) Amenities that include supporting and supporting tourism facilities.

d) Public facilities (Ancillary Service) that support tourism activities.

e) Institutions (Institutions) who have the authority, responsibility and role in supporting the implementation of tourism activities.

Devy and Soemanto (2017: 35), attractiveness in tourism is one of the main capital that must be had in efforts to improve and develop tourist objects and attractions. The existence of Tourism Objects and Attractions is the most important link in a tourism activity, this is due to the main factor that makes visitors or tourists to visit tourist destinations is the potential and attractiveness of these attractions. 
According to Yoeti (2002: 5) tourist attraction is anything that can attract tourists to visit a tourist destination, such as natural attractions, landscapes, beaches, climate and diversity of other destinations, cultural attractions such as history, folklore, typical religious and performance activities as well as artistic value, festivals, social attractions, ways of life, indigenous peoples, languages, building attractions, modern architecture, monuments, parks and water attractions.

Damanik and Weber (2006: 13) state that good tourism attractions are closely related to four things, which are unique, originality, authenticity and diversity. According to Novita Rifaul, et.al (2016: 542) mentions the factors that influence the attractiveness of tourists to visit cultural attractions and their effects on tourist satisfaction, namely cultural factors, uniqueness, promotion, hospitality, cost and quality of service. From the results of the discussion of cultural factors that are proven as determinants of tourists visiting cultural attractions, this is evident from the eigen value of the highest cultural factors. This means that cultural factors have a good influence on tourist visiting decisions. This is inseparable from the dimensions of culture, subculture, and social class.

The existence of Tourism Objects and Attractions is the most important link in a tourism activity, this is due to the main factor that makes visitors or tourists to visit tourist destinations is the potential and attractiveness of these attractions.

\section{Visitor Perception}

Correct perception of an object is needed, because perception is the basis for the formation of attitudes and behavior. An individual's perception of the environment is an important factor because it will continue to determine the individual's actions. Behavior is the result of perception and wrong perception can lead to wrong behavior. The perception of various parties in the development of facilities, services, accommodation, and infrastructure is very important as a first step in the development of a natural tourism object.

According to Saputra (2015: 70) perception is a direct response from an absorption, the process of someone knowing several things through their five senses.

The definition of perception in the narrow sense is vision, how a person sees things, while in the broad sense is a view or understanding, that is how a person views or interprets something.

According to Manalu et al., (2012: 7), perceptions of tourists and communities play an important role in the management of attractions. The community has a supportive perception of the development of attractions as long as the ecotourism activities are not damaging and in accordance with the existing natural conditions. The perception of the community that will assist in the planning and management of attractions in Gunung Luhur, Citorek Kidul Lebak Village, Banten. 
Aspects of perception according to Walgito (2003: 128), namely:

(1) cognitive aspects

This component is based on the knowledge or information a person has about an object. Relating to a person's mind what is in the mind of the consumer. Cognitive is rational, makes sense.

(2) Affective aspects

The affective component is related to pleasure and displeasure, so it is evaluative which is closely related to cultural values or value systems they have. Associated with feelings, are emotional. His form can be in the form of feeling happy, sad, cheerful, and happy.

(3) Conative aspects

Is a person's readiness to behave related to the object of his attitude. Relating to action. His form is a person's actions towards his object.

\section{Research Methodology}

The method in this research is qualitative with a case study approach. By using this type of case study research, this study intends to provide a description of the Tourism Attraction and Perceptions of State Tourism Visitors Above Clouds of Gunung Luhur, Citorek Kidul Lebak Village, Banten, which is being viral on social media. The study was conducted in the Citorek Kidul Lebak Village, Banten, which is known for its country tourism on clouds. In this study will be described in general about the tourist attractions that cause these locations to become viral and know the interest of tourists to visit these locations. The second research focus is the perception of visitors after seeing the tourist attraction and the impression that is felt.

Data collection techniques used are observation, in-depth interviews and documentation. While the validity of the data uses triangulation of sources, triangulation of sources conducted in this study is the results of observations, interviews, and discussions with several other lecturer teams. Using triangulation of this source will direct researchers to collect data required to use a variety of available data sources.

The informants used were interviewing informants consisting of 3 groups, namely the village government, the head of the Banten Tourism Office, Banten tourism activists, the Citorek Village community, and businesses in the area. This study describes the results of the findings obtained from the interviewees, surveys, and conditions directly at the State tourism site above the clouds of Banten Citorek Village.

Data collected includes tourist attractions and visitor perceptions of country tourism on clouds that are being viral. Researchers in taking data by observing or assessing directly in the field. Other criteria that are observed by researchers are recreational activities, environmental cleanliness, safety and comfort of the location as well as the quality of management and services of public tourism on the upper side of Citorek Village, all of which the researchers 
successfully obtained by conducting open interviews with the manager of the tourist attraction, tourist attraction, related agencies, and the community around attractions.

\section{Result and Discussion}

\section{Tourism Overview}

The tour, known as The Country on The Clouds, is located in Citorek Kidul Village, Lebak Banten. Heading to that location can use several alternative routes, such as Bogor, Tangerang, Rangkasbitung, Lebak. The formation of this tourist destination starts from KKN activities carried out by several students and makes some selfies on the hill location that has a height can see the beauty of the village below. The residents finally negotiated and made a tour-aware group (POKDARWIS). Citorek residents make tourist destinations with the aim of enjoying the scenery, the coolness of the village, and selfies (Negeri di Atas Awan).

The view of the country on the clouds really exists in Citorek Village, Gunung Luhur, Lebak Banten. The beauty of the selfie is decorated with some interesting and unique photo spots, including the hands of angels. Visitors are invited to enjoy the scenery with photos on the spot in the form of a hand and leads to the natural scenery of the mountains. Enjoying the beauty of the country photo above the clouds can only be done at 05.00 - 08.00 in the morning. Because at that time the clouds formed a cloud of dew like a cloud, so the atmosphere of the photo was like being in a country above the clouds. This tourist destination is in the sublime mountain region. Towards the location, road signs and information are available. This is fairly complete and prepared, because there is already a signboard that allows visitors to follow the direction of the road. Road facilities are available such as: mosque sign, winding road, downhill road, prone to landslides, there is a mini petrol station, Citorek village head office, signposts to tourist destinations, and the community informs visitors who ask for location.

This tourist destination is in the sublime mountain region. Towards the location, road signs and information are available. Have complete facilities for daily needs, including: prayer rooms, homestays, toilets, restaurants, parking, guide information boards, ticket purchase counters, friendly local guides. The following are some of the research results obtained from surveys, observations, interviews, and data filling. 
Tourism Attractions and Visitors Perceptions on "Negeri di Atas Awan", A New Tourist Destination in Citorek Kidul Lebak Banten

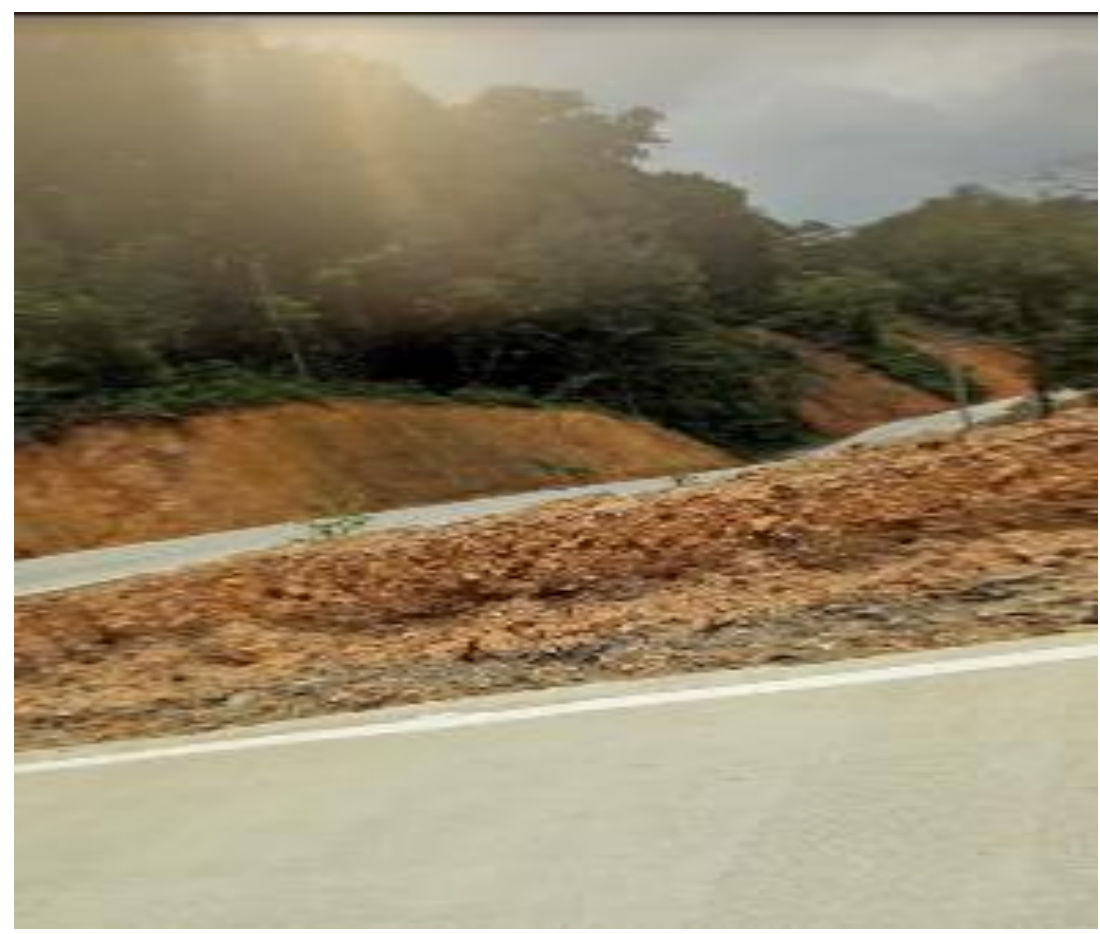

Figure 1. Road Condition

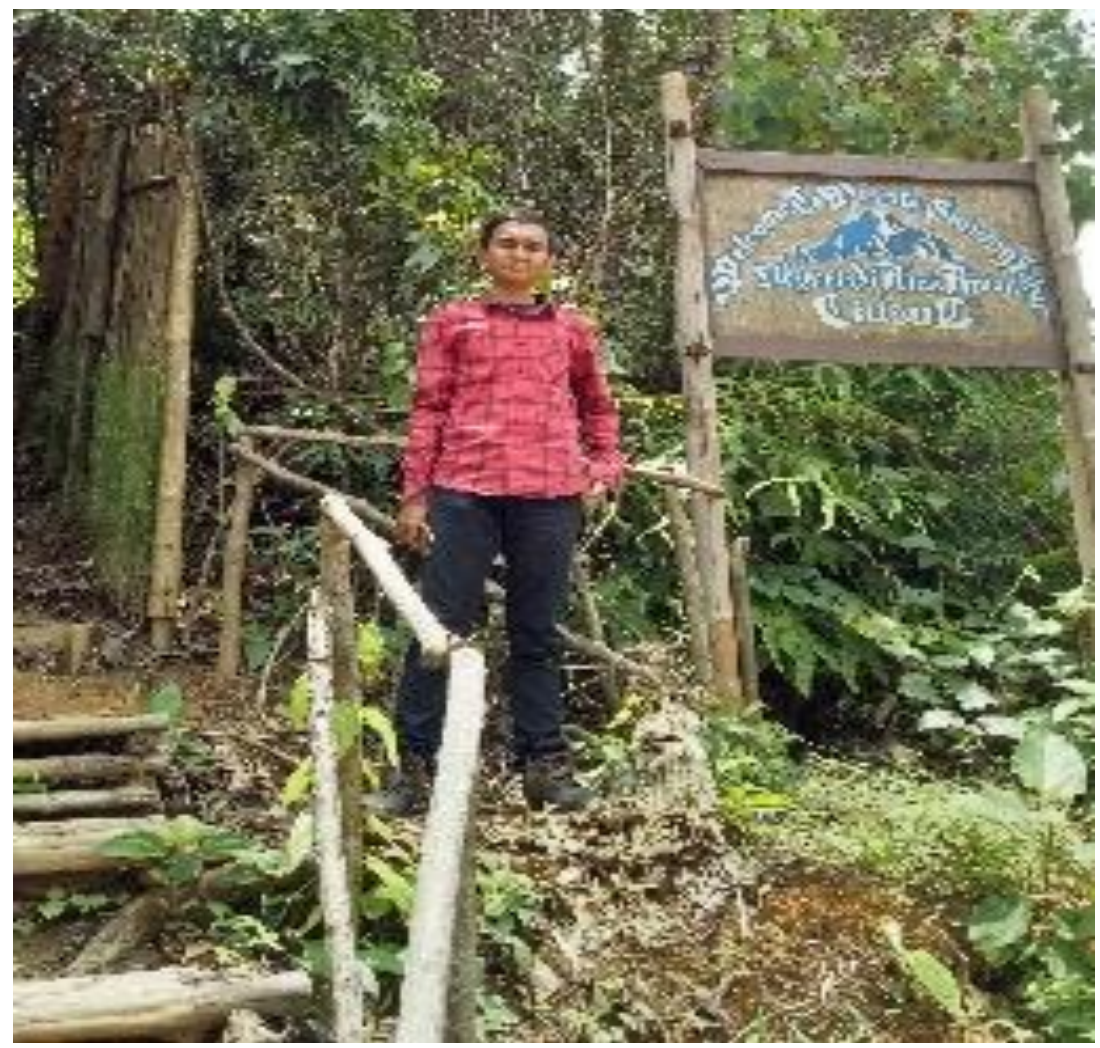

Figure 2. Tourist Trail 
Tourism Attractions and Visitors Perceptions on "Negeri di Atas Awan", A New

Tourist Destination in Citorek Kidul Lebak Banten

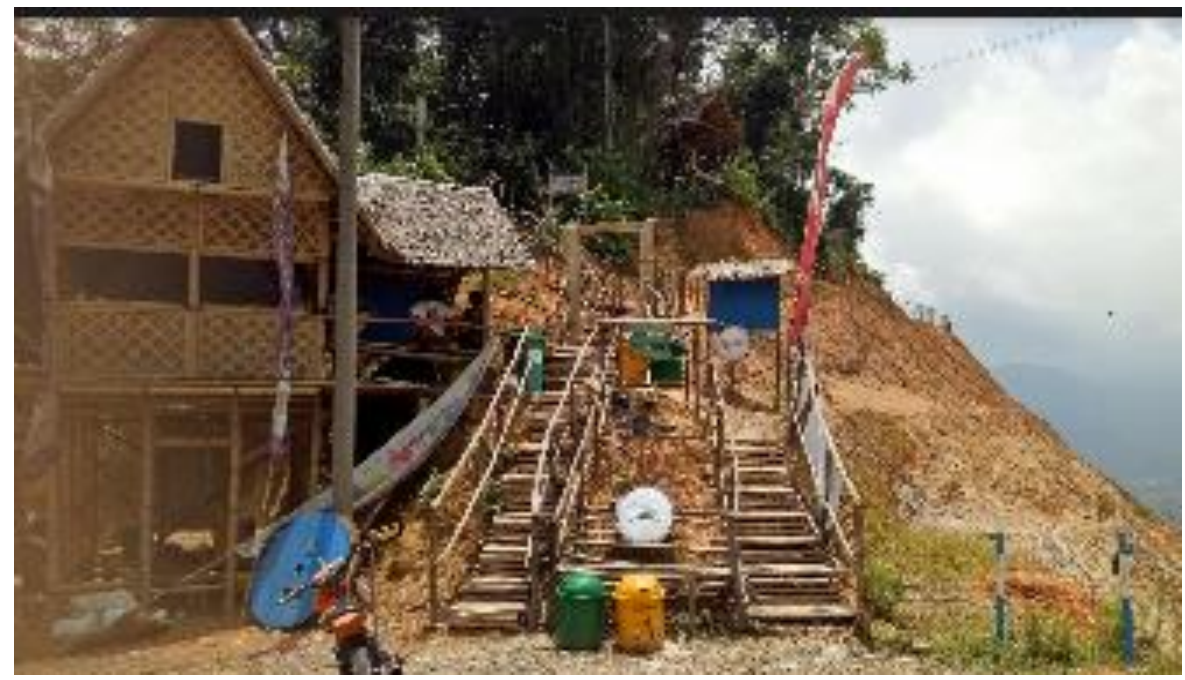

Figure 3. Entrance

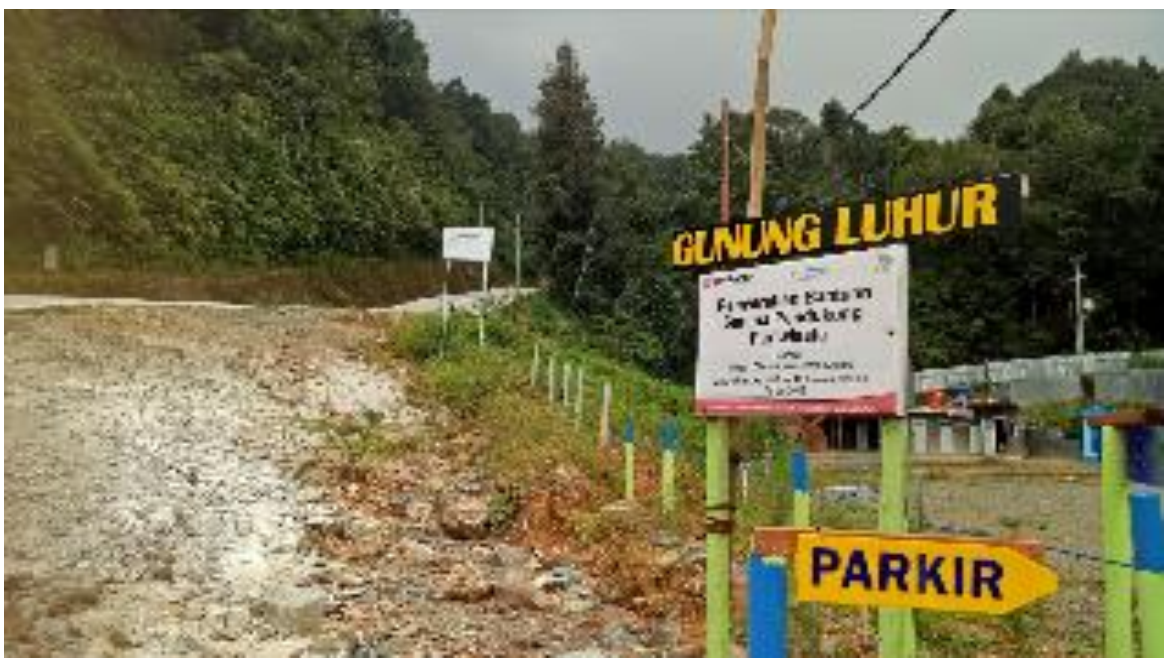

Figure 4. Parking Area

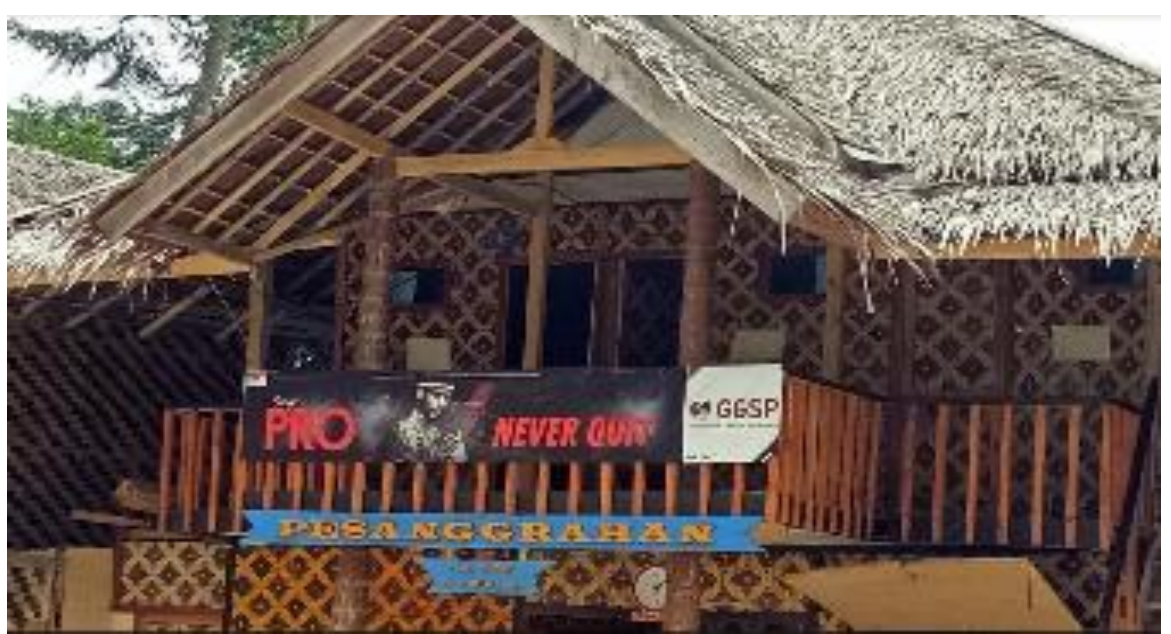

Figure 5. Homestay 


\section{Research result}

\section{Tourist attraction}

Based on the results of research from case studies found that visitors to the tourist destination "Negeri di Atas Awan" in September - December 2019 reached 30,000 people. But there are some who argue in social media that Citorek Lebak Banten does not have these attractions. Research conducted in March 2020 that "Negeri di Atas Awan" does exist in Citorek Lebak, Banten. Scenery conditions such as the country above the clouds can be enjoyed for some time, only before sunrise. The tourists who came were from: Tangerang, Jakarta, Bogor, Banten, Bekasi. The visitors come at night, before sunrise, and some even stay at the homestay.

The number of visitors in the current condition that is March 2020 reached 97 people, because the access road cannot be traversed by cars due to landslides and flash floods in early 2020. The main road to the location is in the process of being repaired, because the connecting bridge is broken so it cannot be passed by vehicles 4 wheels.

A tourist attraction must have several aspects, then it is reviewed as follows: a) Attraction

"Country Above the Clouds" provides a tourist attraction in the sight of a country that is above the clouds. The natural village of Citorek, Mount Luhur is at an elevation that gives beautiful natural beauty. Nature that can be seen as being above the clouds can be enjoyed at certain times, namely at $05.00-08.00 \mathrm{WIB}$.

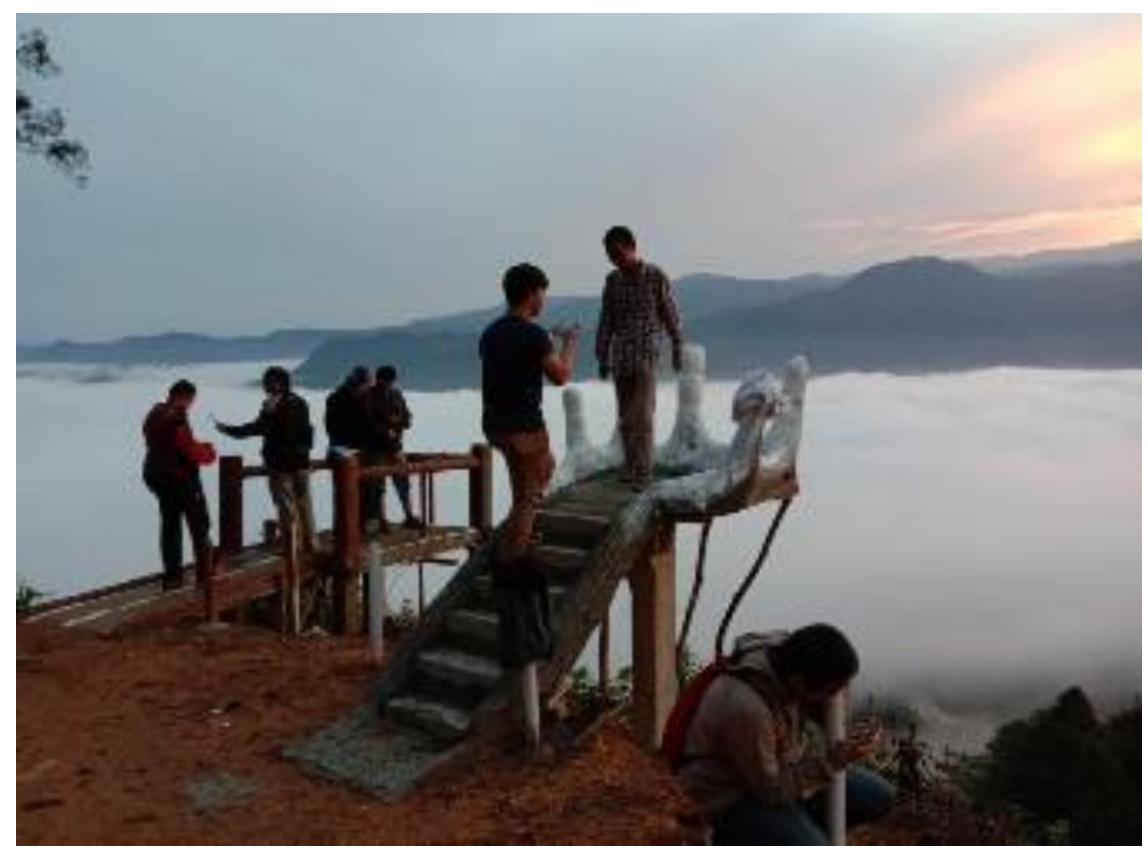

Figure 6. Sights of attractions 


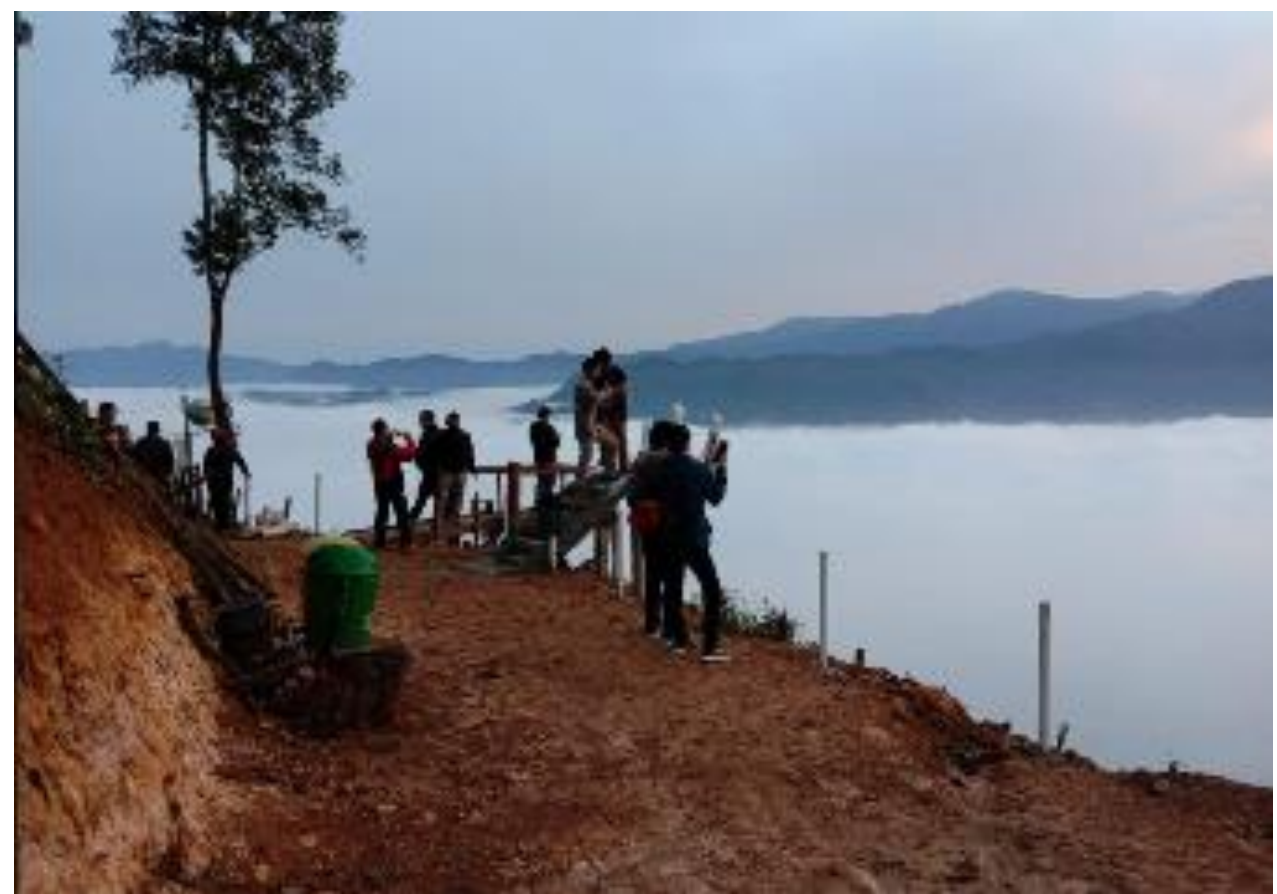

Figure 7 . The condition of the tourist attraction

b) Accessibility

Accessibility to tourist sites can be reached by bus, train, private vehicle, and continued with motorcycle taxi services (because the condition of the road access is being improved due to flash floods). The road to the tourist location is winding with good road conditions. The road sign to the tourist location is also complete (mosque information, downhill, upward, tourist path info, etc.). Mini gas stations are available to refuel vehicles.

c) Amenities

Tourism support facilities are already available in Citorek Village, Lebak Banten. There are public facilities for tourist sites, such as: toilets, parking, small mosque, ticket counter, homestay, and restaurant. Seeing the condition of the complete facilities, this tourist destination was prepared by the community. The power of togetherness of the Citorek Village community that made the new tour "Negeri di Atas Awan" was well implemented. But there are indeed some photo spots and paths to the location of the cloud scenery that need to be renovated, to make it look more beautiful and comfortable. There are several photo spots, flaying fox, a place to enjoy the view of the clouds.

d) Public facilities (Ancillary Service)

Public facilities at the tourist site "Negeri di Atas Awan" are complete, the manager is Pokdarwis and residents who have a business together to build this location with public facilities, such as: toilets, parking, small mosque, ticket purchase counters, homestays, and restaurants. 
e) Institutions

This tourism destination institution was formed from the self-help community of Citorek Village, Lebak Banten. The residents formed Pokdarwis (Tourism Awareness Group) which together built their village into a tourist destination. Furthermore, after viral on social media, the local government responded and helped in the construction of access roads and was preparing for the construction of the mosque. The results of this study came from open interviews with residents who participated in building attractions, Pokdarwis, and visitors.

\section{Tourist Visitors' Perception}

The results of research on the perception of visitors that "Negeri di Atas Awan" when the viral and famous with destination "Negeri di Atas Awan" by one of the residents and visitors reached 1,000 people. But the manager of this tourist destination is not ready to accommodate too many visitors. Because the point of location is neutralized and visitors want to know that is photos with views of the country above the clouds.

The results of this study are consistent with the observations found and use Walgito's perception theory, as follows:

(1) Cognitive Aspects

This component is based on the knowledge or information a person has about an object. The visitor's knowledge of the tourist attraction "Negeri di Atas Awan" is a view like a cloud and visitors are close to the clouds. The visitors know this tourist destination from social media, such as: Instagram, Facebook and YouTube. Described there is a view of white clouds and some visitors who have taken pictures with the view.

(2) Affective aspects

The affective component is related to feeling and emotional. In the affective aspect, based on the results of interviews with visitors that they feel happy, can release fatigue, and can feel the cool nature of Citorek. Towards the tourist destination area "Negeri di Atas Awan" must go through the ascending and descending paths. The visitors feel a pleasant and tense experience when going through the winding, uphill, and downhill.

(3) Conative aspects

In the conative aspect carried out by visitors while in the location of "Negeri di Atas Awan" that is taking pictures with views of clouds (actually dew forming like clouds) and expression. Some photo spots are used by visitors to capture images there. There are some visitors who already know information about this tourist destination, so they are willing to come at night, until staying at the location. 


\section{F. Conclusion}

Based on the results of research that the tourist attraction "Negeri di Atas Awan" is the view of clouds formed from the cold weather in the Citorek Village. This view can only be enjoyed at $05.00-08.00 \mathrm{WIB}$. Accessibility to this tourist destination is good, but currently in March is under repair because access to the bridge affected by flash floods, is expected to be completed by the end of April 2020. This tourist destination provides several photo spots to capture the moment being there. The results of the visitor's perception of the study expressed satisfaction, because news that was released through social media was true. Even though going to a tourist destination requires time to feel the access of winding, up and down roads. Everything felt in accordance with what was obtained while in the location. Visitors who already know the tour, are willing to come at night, even staying at a homestay that is not too large in size.

\section{REFERENCES}

Damanik, Janianton dan Helmut F. Weber. (2006). Perencanaan Ekowisata. Yogyakarta : CV Andi Offset.

Devy, Helln Angga dan R.B. Soemanto. (2017). Pengembangan Obyek dan Daya Tarik Wisata Alam Sebagai Daerah Tujuan Wisata di Kabupaten Karanganyar (Studi Kasus Obyek Wisata Air Terjun Jumog di Kawasan Wisata Desa Berjo, Kecamatan Ngargoyoso, Kabupaten Karanganyar). Jurnal Sosiologi DILEMA. Vol. 32. No. 1. ISSN : 0215/9635.

Manalu, B.E., Latifa, S. dan Patana, P. (2012). Persepsi Masyarakat Terhadap Pengembangan Ekowisata di Desa Huta Ginjang, Kecamatan Sianjur MulaMula, Kabupaten Samosir, Provinsi Sumatera Utara. Jurnal Penelitian. 1(3): 511.

Novita Rifaul, et.al. (2016). Faktor-Faktor Penentu Daya Tarik Wisata Budaya Dan Pengarubnya Terhadap Kepuasan Wisatawan, Jurnal Pendidikan : Teori, Penelitian, dan Pengembangan Volume: 1 Nomor: 3 Bulan Maret. Halaman: 536_546.

Nazmudin, Acep. (2019). https:/ / regional.kompas.com/read/2019/09/23/06050061/5-fakta-

negeri-di-atas-awan-viral-di-media-sosial-hingga-diusulkan-jadi?page $=$ all

Saputra, M. E. (2015). Persepsi Masyarakat Terhadap Manfaat Lingkungan Obyek Wisata Sungai Korumba di Kawasan Tabura Nipa-Nipa Kelurahan Alolama Kecamatan Mandonga Kota Kendari. Skripsi. Universitas Halu Oleo. Kendari.

Sunaryo, Bambang. (2013). Kebijakan Pembangunan Destinasi Pariwisata Konsep dan Aplikasinya di Indonesia. Yogyakarta : Gava Media.

Yoeti, Oka A. (2008). Perencanaan dan Pengembangan Pariwisata. Jakarta : Pradnya Paramita.

Walgito, Bimo. (2003). Pengantar Psikologi Umum. Yogyakarta: Andi Offset. 